\title{
Using BPMN to Identify Indicators for Teacher Intervention in Support of Self-regulation and Co-regulation of Learning in Asynchronous e-learning
}

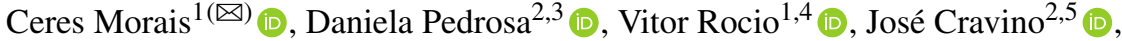 \\ and Leonel Morgado ${ }^{1,4}$ (D) \\ 1 INESC TEC, Porto, Portugal \\ ceres.g.morais@inesctec.pt, \{vjr, leonel.morgado\}@uab.pt \\ 2 CIDTFF, Aveiro, Portugal \\ dpedrosa@ua.pt, jcravino@utad.pt \\ 3 University of Aveiro, Aveiro, Portugal \\ ${ }^{4}$ Universidade Aberta, Lisbon, Portugal \\ 5 University of Trás-dos-Montes e Alto Douro, Vila Real, Portugal
}

\begin{abstract}
We used BPMN diagrams to identify indicators that can assist teachers in their intervention actions to support students' self-regulation and co-regulation in an asynchronous e-learning context. The use of BPMN modeling, by making explicit the tasks and procedures implicit in the intervention of the e-learning teacher, also exposed which data were available for developing decision-support indicators, as well as the relevant moments for carrying out interventions. Such indicators can help e-learning teachers focus their interventions to support selfregulation and co-regulation of learning, as well as enabling the creation of live data dashboards to support decision-making for those interventions, thus this process can contribute to devise better instruments for teacher intervention in support of self-regulation and co-regulation of student learning.
\end{abstract}

Keywords: Self-regulation · Co-regulation · Indicators $\cdot$ BPMN $\cdot$ Dashboards · e-learning

\section{Introduction}

Teaching support for self and co-regulation of learning (SCRL) is crucial for the academic success of students as well as to prevent dropout during their studies. In e-learning contexts, occasions for synchronous contact between teacher and students are limited or absent, which is a further challenge to identify needs to support students' SCRL.

We used a business process improvement technique to explain and reveal the activities of the stakeholders in an e-learning engineering course: visual modeling with the graphic notation BPMN (Business Process Model and Notation) [1]. This contributed to the course planning, clarifying teaching actions, and revealing opportunities to intervene in support of self and co-regulation of learning [2]. 
Using the BPMN models, we matched the intervention opportunities with the data available on e-learning platforms. This allowed us to identify relevant indicators to support the teacher's intervention towards self and co-regulation of students' e-learning. Such indicators can be used to create live monitoring tools, thus streamlining teachers' decision-making process for intervening in this regard.

\section{Related Work}

Improving processes requires awareness of their realities and context. In human contexts, processes are typically complex and negotiated, relying on both explicit and implicit rules, expectations, and assumptions. While this reliance means human-involving processes are rich, diversified, and versatile, it also means their improvement is cumbersome, conflicting, and hard. A common technique employed to tackle this difficulty is rendering explicit what is implicit, so that assumptions and contradictions can be visualized and addressed. BPMN is a commonly-used notation employed in business and organizations in general for this purpose.

In educational planning and learning design, several techniques have been used over time to render explicit the implicit, such as descriptive narratives, planning templates or forms (e.g. tabular/matrix representations), conceptual maps (e.g. mind maps and other dendrograms), and several types of diagrams, detailing workflows, actor participation, or other dimensions [3]. More formal approaches employ instructional design languages, with the IMS LD model being the most common [4]. These are detailed and powerful, able to express the pedagogical activities, as tested by researchers at the Open University of the Netherlands [5]. However, their focus is mostly in automating the generation and tracking of the online activities, rather than supporting human-led analysis and improvement of processes involving humans, such as teacher decision-making in support of student actions, such as SCRL.

Self-regulated learning (SRL) is considered as a meta-process in which students have control of their behaviour, emotion, motivation and cognition through the use of personal strategies to achieve the goals they have established [6, 7], and are proactive in managing their learning. In its turn, co-regulated learning (CRL) is understood as a social regulation of learning, in which students regulate their cognition, behaviour, motivation and their emotion in coordination of regulation between the student and other people (teachers or peers) [8]. CRL helps understand the SRL process [9].

Distance Learning (DL) courses present higher dropout rates, indicating greater hurdles [10]. The plan, development, and adequate use of SCRL skills are some of the difficulties faced by DL students [11, 12]. Also, they lack immediate support, in a context of potential social isolation [11-14], which are challenges for teacher development of effective pedagogical strategies [15]. Author's earlier work [14] identified some of these challenges: reduced cooperation, gradual missing of deadlines, prioritization of SCRL aspects; development of processes and tools to promote SCRL in teaching-learning of programming, engaging students on effective planning, organizing and management of their learning methods, and creating socialization opportunities. Teachers also found it difficult to gain awareness of class dynamics and provide immediate feedback. These support the relevance of developing pedagogical and instructional design techniques supporting student development of SCRL strategies [16]. 
A literature review [17] identified the need to create models that allow students to combine their activity with the tools that allow them to monitor the use of SRL strategies in online platforms. However, existing tools have not offered sufficient detail about students' activities and mechanisms to support SRL strategies. Thus, it is essential that in the design process phase of the tools, the relationships that are established between the student's activities, the SRL strategy to be developed and how this tool accompanies and supports these activities can be clarified through indicators. Since they identified the gap "that there is no guide for the design, implementation and evaluation of this type of tools." (ibid.) In addition, evidence from Learning Analytics to support teaching is rarely reported [18].

The literature on learning analytics recommends that inferences about learners' SRL and metacognitive control should be supported by trace data (e.g., logs) and shown as "observable indicators" [19]. For that, an analytics system must perform calculations based on action tracing and generate indicators leading to recommendations for change. Three dimensions should be considered when analyzing SLR traces in asynchronous online learning environments [20]:

1. Time investment in content learning: indicators such as how students allocate and spend time. Teachers must adopt strategies that lead students to define their learning goals and assess their performance. Associated indicators are: the student's learning time and attention level, as found in log traces.

2. Study regularity and time management strategy: indicators such as the regularity of access to the e-learning platform, the student's learning status, and time devoted to studying. Time management is promoted by maintaining regular contact and communication between teachers and students. This includes e-mailing to encourage students' progress monitoring and revising of their planning.

3. Activate help-seeking: indicators such as questions asked by students, students reading questions placed by their colleagues, and reading of the teacher's replies. Complementary aspects include the number of messages, time and frequency of reading and/or interaction. Reading metacognitive feedback is also an indicator supporting help-seeking skills.

While the first dimension is the foremost one, the others, related to students' ability to follow the discussion flow, enable adjustment and monitoring of their performance and learning objectives. Students self-monitoring through such indicators of tracking log data are able to check their learning progress and compare it with their peers.

Approaches bringing into e-learning process-improvement techniques from businesses and organizations, have thus been emerging. BPMN is a case of one such technique showing promise for improvement of educational processes, for instance by modelling collaboration activities in massive online courses [21]. BPMN's ability to represent alternative pathways instead of a single, strict e-learning process, documenting the rich and dynamic nature of e-learning processes, enabled researchers to get enhanced feedback on e-learning processes from a variety of stakeholders and experts [22]. BPMN has also been used to combine activities of different users, modelling a learning path with associated goals and activities [23]. 


\section{Detecting Opportunities for Teacher Support of SCRL of e-learning Activities Using BPMN}

We have employed BPMN diagrams in the planning of an asynchronous e-learning course on software engineering at Universidade Aberta (UAb) - Portugal, to expose the foreseen teaching and learning activities of course participants, mediated by the e-learning platform [2]. Being an asynchronous course, there is no required schedule for students to meet online with the lecturer. Instead, discussions and other dynamics take place by posting messages in forums or similar platforms, or by separately editing/commenting on shared media during a set period for completion of activities.

The joint involvement of lecturer and researchers in the development of the BPMN diagrams clarified the implicit activities of teachers in this asynchronous environment, rendering them explicit. Those activities stem from the virtual pedagogic model of UAb [24], which foresees that teachers must support student-centered learning with adequate guidance, as a facilitator of the learning process, promoting reflection and sharing within the group of students, and moderating interactions. UAb also requires that teachers be aware of the needs and difficulties expressed by students, responding to their queries within $48 \mathrm{~h}$ of working days [25].

An example is provided in Fig. 1, detailing one of the first course activities: reading and debating the syllabus (PUC, "Plano de Unidade Curricular"), suggesting possible adjustments. The BPMN process, involving the lecturer throughout, yielded this explicit rendering of teaching activities, enabling us to detect opportunities for teaching intervention in support of self- and co-regulated learning.

The model in Fig. 1 has three pools (labelled rectangles identifying participants' actions): Students, Platform, and Teacher. The online activities of the students are recorded in the platform, hence its central placement as a mediator participant.

The core activity, from a student perspective, is plain: read the syllabus (PUC), and discuss it in the appropriate course forum. This can occur at any moment during a given period at the beginning of the semester For this lecturer, this was two weeks.

However, from a teacher's perspective, one must consider the university's pedagogic model and its requirements, as above. Since teachers must respond within $48 \mathrm{~h}$ of working days, it makes sense to use this period for checking up on class status for intervention needs. The need to render explicit this check/intervention process revealed that it was not identical throughout the two-week period:

1. Milestone 1. Early in the process, the teacher was more concerned with awareness of overall class dynamics, rather than individual students, due to their demographics: being working students, many would plan for weekend study rather than moonlight study. Thus, it's too early for the teacher to provide unrequested individualized self-regulation support, which might be understood as undue pressure. Instead, considering the overall class dynamic could be more significant, providing class-level encouragement. This encouragement can be motivational, self-regulation advice, or promoting co-regulation, and being provided at a class level will reach those that may benefit from it, without undue pressure on those that don't. Individual feedback is due, however, for students who have already engaged in the activity (debating the syllabus). This led to Realization 1: the need to consider two different teacher 


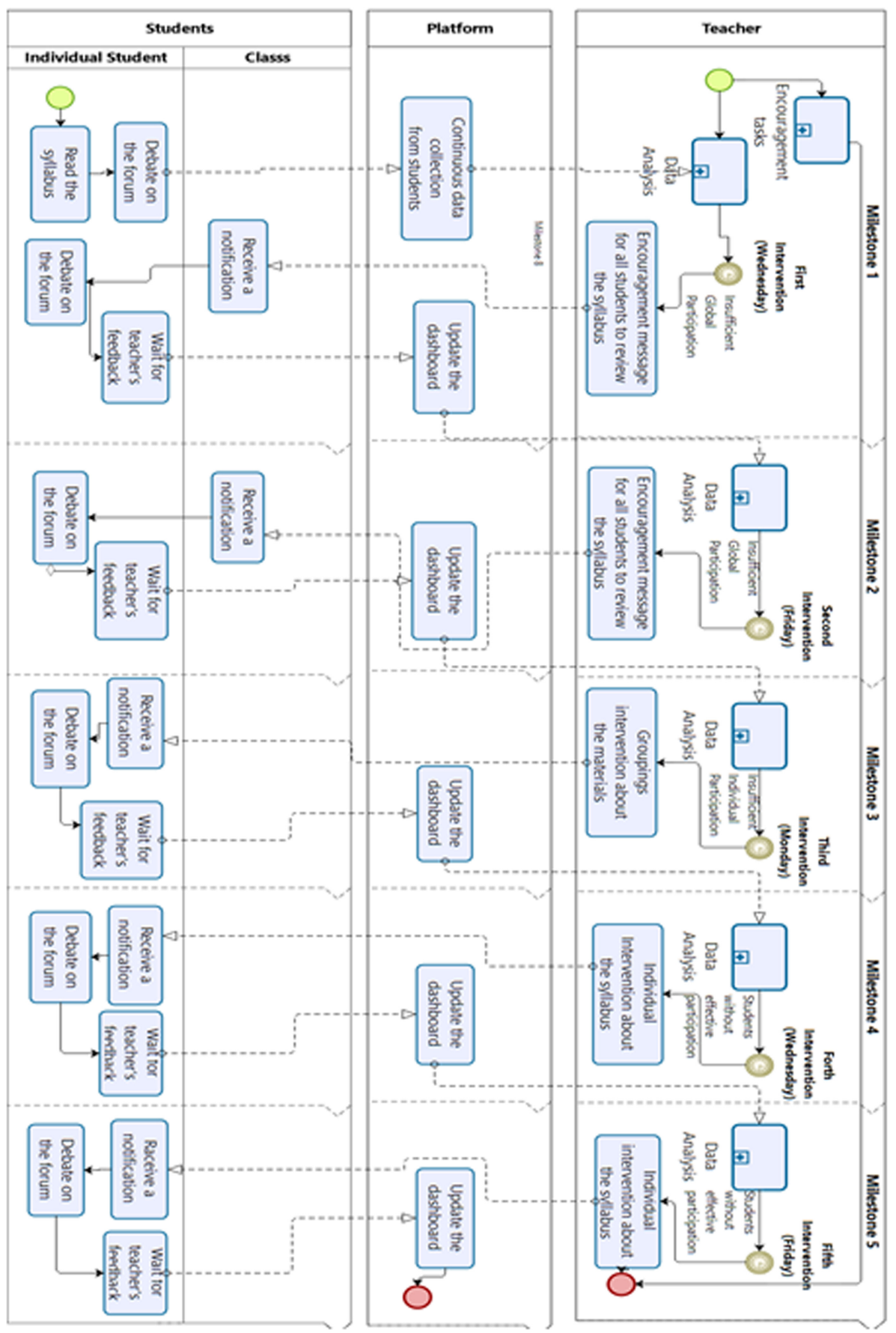

Fig. 1. BPMN diagram of tasks for visualization and participation in the syllabus forum 
awareness approaches, reflected in two BPMN swimlanes within the Students pool: Individual Students and Class.

2. Milestone 2. The teacher reckoned that when checking up just before the weekend, an adequate intervention in support of self-regulation and co-regulation was to remind students that a prime occasion for study might be due. This led to Realization 2: Each intervention stemming from a check-up might lead to a different opportunity for self-regulation and co-regulation, identified as BPMN milestones.

3. Milestone 3. Once the first weekend has elapsed, the teacher intervention changes from class dynamics to groupings of individuals: any student who has not participated is now having less opportunities to do so. Specific analysis is due, to identify categories of individual situations: which students have not even accessed the syllabus? which have but did not contribute in the forum? which did but only inconsequential remarks? etc. While individuals in these categories need to be approached by personal messages, these can still be customized to the larger category context, since a full week is still available for student participation. This led to Realization 3: teacher interaction opportunities in week 2 shift in focus from co-regulation to self-regulation, but individuals are still part of groupings.

4. Milestone 4: midway through the final week of the topic, students who still have not achieved adequate participation require further support, and this led to Realization 4: the teacher interaction focus must shift to the individual, with personalized messages.

5. Milestone 5: before the final weekend of the topic, which for some students will be the last chance to participate within the allocated time frame, the teacher intervention must be tailored to specific situations of any remaining individuals. This led to Realization 5: the final interaction must consider not just individualized messages, but any personal student history details that may be useful to encourage use of this last chance for participation.

\section{Identifying Data in Support of Teacher Interventions}

The realizations of BPMN modelling, described in the previous section, point towards different levels of informational needs in support of teacher's decision-making for intervening in support of students' self- and co-regulation of learning.

Depending on each institution's choice of e-learning platform, different data sources may be available to provide that information. At Universidade Aberta, the Moodle elearning platform is used. Table 1 matches the informational needs of the teacher of this course to guide teaching interventions at each milestone, with the available data in Moodle to provide that information.

The data required to perform the activities of milestones 1 to 5 can be obtained through Moodle's Web Services, according to Moodle's Application Programming Interface (API) [26]. They can also be obtained by having teachers manually export them using Moodle's log export features. These sources are clarified in Tables 2 and 3, below. 
Table 1. Teacher information needs at each milestone, and available Moodle data

\begin{tabular}{|c|c|c|}
\hline Milestone & Teacher information needs & Available Moodle data \\
\hline 1 & $\begin{array}{l}\text { Overall level of class participation } \\
\text { (syllabus access and forum } \\
\text { posting/debating, level of peer } \\
\text { interaction) } \\
\text { Contributions of students who have } \\
\text { already engaged in debating the syllabus }\end{array}$ & $\begin{array}{l}\text { List of students who accessed each page } \\
\text { of the syllabus; Threads initiated by } \\
\text { students (date, hour, author, and } \\
\text { content); Replies to current threads } \\
\text { (date, hour, author, and content); } \\
\text { Individual reading (viewing) of threads } \\
\text { (author, date and hour) }\end{array}$ \\
\hline 2 & Idem & Idem \\
\hline 3 & $\begin{array}{l}\text { Groupings of students by category of } \\
\text { participation, with relative prevalence of } \\
\text { each grouping }\end{array}$ & Idem \\
\hline 4 & $\begin{array}{l}\text { Individual students with insufficient } \\
\text { participation and contribution }\end{array}$ & Idem \\
\hline 5 & $\begin{array}{l}\text { Individual students with insufficient } \\
\text { participation and contribution, and their } \\
\text { personal student history }\end{array}$ & $\begin{array}{l}\text { Idem. + each individual student's } \\
\text { history of access to prior resources, } \\
\text { participation in prior forums, and } \\
\text { submission of prior assignments }\end{array}$ \\
\hline
\end{tabular}

Table 2. Web services to obtain data for Milestones 1-4

\begin{tabular}{l|l|l}
\hline Data & WebService/Log export & Description \\
\hline $\begin{array}{l}\text { List of students who } \\
\text { accessed the syllabus }\end{array}$ & Log export & $\begin{array}{l}\text { Get records on resource } \\
\text { (book) use by students }\end{array}$ \\
\hline $\begin{array}{l}\text { Threads initiated by } \\
\text { students (date, hour, } \\
\text { author, and content) }\end{array}$ & mod_forum_get_forum_discussions & $\begin{array}{l}\text { Get a list of forum } \\
\text { threads, with date, hour, } \\
\text { author and content }\end{array}$ \\
\cline { 2 - 3 } & mod_forum_get_forum_discussion_posts & $\begin{array}{l}\text { Get the list of forum } \\
\text { posts for a given thread }\end{array}$ \\
\cline { 2 - 3 } & mod_forum_get_discussion_post & $\begin{array}{l}\text { Get a thread's opening } \\
\text { post with date, hour, } \\
\text { author and content }\end{array}$ \\
\hline $\begin{array}{l}\text { Replies to current } \\
\text { threads }\end{array}$ & mod_forum_get_discussion_posts & $\begin{array}{l}\text { Gets a list of posts for a } \\
\text { thread }\end{array}$ \\
\cline { 2 - 3 } & mod_forum_get_discussion_post & $\begin{array}{l}\text { Get a specific post with } \\
\text { date, hour, author and } \\
\text { content }\end{array}$ \\
\hline $\begin{array}{l}\text { Individual reading } \\
\text { (views) of threads }\end{array}$ & Log export & $\begin{array}{l}\text { Get records on thread } \\
\text { (discussion) access by } \\
\text { students }\end{array}$ \\
\hline
\end{tabular}


Table 3. Web services to obtain specific data for Milestone 5

\begin{tabular}{l|l|l}
\hline Data & WebService/Log export & Description \\
\hline $\begin{array}{l}\text { Student's history of } \\
\text { access to prior } \\
\text { resources }\end{array}$ & Log export & $\begin{array}{l}\text { Get the student's history of access } \\
\text { to prior resources with date, hour, } \\
\text { author and resource accessed }\end{array}$ \\
\hline $\begin{array}{l}\text { Student's history of } \\
\text { participation in prior } \\
\text { forums }\end{array}$ & Log export & $\begin{array}{l}\text { Get the student's history of access } \\
\text { to prior forums }\end{array}$ \\
\hline $\begin{array}{l}\text { Student's history of } \\
\text { submission of prior } \\
\text { assignments }\end{array}$ & mod_assign_list_participants & $\begin{array}{l}\text { Get the list of students who } \\
\text { participated in an assignment, } \\
\text { with grading status }\end{array}$ \\
\hline
\end{tabular}

\section{Indicator for Teacher Intervention in Support of SCRL}

The identification of necessary information, using the BPMN notation process, and the identification of available data to provide that information, done in Table 1, and of the feasibility of lifting those data from the learning platform, shown in Tables 2 and 3, enabled us to ascertain indicators towards teachers' process of decision-making. By considering the live status of these indicators, an e-teacher can intervene with greater focus in support of students' self and co-regulation of learning. Table 4 showcases how the indicators can be drawn from the available data.

With these indicators, one aims to promote teacher awareness: "the sense of the perceptual processes in order to assess how the learning situation evolves" [27]. In particular, to identify and address students' need for support in their self-regulation processes [28]. A typical approach is to present these indicators visually as dashboards, instead of having to analyze raw data on a daily basis on the e-learning platform itself. Since the teacher already has multiple tasks to develop throughout a course, providing a tool that streamlines this analysis can be transformative. From the perspective of SRL, dashboards are enablers, contrasting goals vs. Current state [29]. Research that supports the effects of learning analysis dashboards concludes that such tools contribute to student self-reflection and strategic action for establishing SRL [28].

In addition to checking the students' self-regulation status, it is possible to check how students interact within the e-learning platform with each other, to identify their co-regulation status. This can reveal progress and potential problems. Moreover, processoriented feedback would help teachers and students improve engagement and task performance [30], supporting students' co-regulation. To further the analysis, dashboards should be taken into account as decision-making tools, amplifying or directing cognition, and capitalizing on human perceptual capacities [31]. 
Table 4. Indicators per milestones

\begin{tabular}{|c|c|c|}
\hline Milestone & Indicators & Data \\
\hline \multirow[t]{6}{*}{1} & $\begin{array}{l}\text { Percentage of students who accessed the } \\
\text { syllabus }\end{array}$ & $\begin{array}{l}\text { \#(list of students who accessed the } \\
\text { syllabus)/Total students in the class }\end{array}$ \\
\hline & $\begin{array}{l}\text { Percentage of students who accessed all } \\
\text { pages of the syllabus }\end{array}$ & $\begin{array}{l}\text { \#(list of students who accessed all } \\
\text { pages of the syllabus)/Total students in } \\
\text { the class }\end{array}$ \\
\hline & $\begin{array}{l}\text { Percentage of students who did not } \\
\text { access all pages of the syllabus }\end{array}$ & $\begin{array}{l}\text { (Total students in the class - Size of the } \\
\text { list of students who accessed all pages } \\
\text { of the syllabus)/Total students in the } \\
\text { class }\end{array}$ \\
\hline & $\begin{array}{l}\text { Percentage of students taking the } \\
\text { initiative to start threads }\end{array}$ & $\begin{array}{l}\text { Count different authors in }\{\text { Number of } \\
\text { threads initiated by students }\} / \text { Total } \\
\text { students in the class }\end{array}$ \\
\hline & $\begin{array}{l}\text { Percentage of students who read the } \\
\text { threads }\end{array}$ & $\begin{array}{l}\text { Number of different students reading } \\
\text { threads/Total students in the class }\end{array}$ \\
\hline & $\begin{array}{l}\text { Percentage of students who replied to } \\
\text { other's threads }\end{array}$ & $\begin{array}{l}\text { Count different authors in \{for each } \\
\text { thread, list different authors in replies } \\
\text { that are not the original post's } \\
\text { author\}/Total students in the class }\end{array}$ \\
\hline 2 & Idem & Idem \\
\hline 3 & $\begin{array}{l}\text { Percentage of students per participation } \\
\text { category (from no access to resources } \\
\text { and no contributions; up to access to all } \\
\text { resources and contribution both by } \\
\text { creating threads and by responding to } \\
\text { other students' threads) }\end{array}$ & $\begin{array}{l}\text { Number of different students in each } \\
\text { category/Total students in the class }\end{array}$ \\
\hline 4 & $\begin{array}{l}\text { List of students per lower participation } \\
\text { categories }\end{array}$ & $\begin{array}{l}\text { List of students in each category } \\
\text { expunged of students in higher } \\
\text { participation categories }\end{array}$ \\
\hline \multirow[t]{4}{*}{5} & Idem Milestone $4+$ & Idem. $4+$ \\
\hline & $\begin{array}{l}\text { Relative access to prior resources of each } \\
\text { individual student in lower participation } \\
\text { categories for the current activity }\end{array}$ & $\begin{array}{l}\text { Student's history of access to prior } \\
\text { resources/Average of class access to } \\
\text { prior resources }\end{array}$ \\
\hline & $\begin{array}{l}\text { Relative participation in prior forums of } \\
\text { each individual student in lower } \\
\text { participation categories for the current } \\
\text { activity }\end{array}$ & $\begin{array}{l}\text { Student's history of participation in } \\
\text { prior forums/Average of class } \\
\text { participation in prior forums }\end{array}$ \\
\hline & $\begin{array}{l}\text { Relative participation in prior } \\
\text { assignments of each individual student } \\
\text { in lower participation categories for the } \\
\text { current activity }\end{array}$ & $\begin{array}{l}\text { Student's history of submissions to } \\
\text { prior assignments/Average of class } \\
\text { submissions to prior assignments }\end{array}$ \\
\hline
\end{tabular}




\section{Discussion}

The starting point for discovering opportunities in which the teacher can interact with students to support them in the process of self and co-regulation was given through the BPMN modeling developed with the teacher. The modeling allowed us to be aware of actual activities demanded by the different actors of the process, whether students, teachers or the e-learning platform itself, corroborating prior research [23].

The definition of participation milestones was one of the aspects that emerged from this aspect. It enabled us to clarify, at each one, what teacher interventions were being considered, what would determine them, and how to proceed to assist the self and coregulation of students. This clarity helps minimize one of the challenges reported, the need for timely feedback from the teacher and intervention $[14,15]$.

The novel aspect of this work is identifying what data needs to be extracted from the e-learning environment to carry out these interventions: their consideration, decisionmaking, and actual process. For example, one can consider the 3 dimensions recommended by Kim et al. [20]: time investment in content learning, study regularity and time management strategy, and activate help-seeking. With the identified data indicators above, one can use these dimensions at each of the specified milestones. For example, by using indicators for Milestone 1 from Table 4, one can ascertain whether the class has started to invest time in content learning; with the same indicators for Milestone 2, one can ascertain if more time was invested or not. And similar analysis can be made with other indicators at other milestones, moving from class-level analysis to individuals'.

\section{Conclusions}

Indicators such as the ones we identified for the activity analyzed in this paper can help e-learning teachers guide their interventions in support of SCRL: with them indicators, a more aware teacher has more latitude to decide how to support the students, considering pedagogical strategies [16] to promote students SCRL strategies [6, 7]. Awareness aspects promoted by the indicators include time management (time students devoted to carrying out tasks); focus of students' learning (initiative for initiation of threads vs. Passive status); and student's contact/interaction with colleagues and the teacher (reading of threads, replying to threads).

The visualization and interpretation of student participation data can be streamline by automation, using tools such as dashboards. This can contribute to the dissemination of these benefits throughout courses, programs, and even entire institutions. Identifying indicators for such tools is a major aspect of their development, even mentioned as the major gap in tools to support self-regulation [17]. The process herein, of using BPMN to identify information needs, and then follow from those to assess available data and construct indicators towards those needs, is a method for the design, implementation and evaluation of such tools.

To validate the relevance of these (or other) indicators obtained via this method, actual instruments should be developed to provide teachers with this information in real time, so that an analysis of their impact on teacher interventions can be pursued. We plan on creating dashboards to guide teacher interventions in support of their students' 
SCRL, as a means to analyze the relevance of these indicators, refine them, or identify new ones. The ultimate goal is contributing to teachers' and students' learning success.

Acknowledgements. This work is co-financed by the ERDF - European Regional Development Fund through the Operational Programme for Competitiveness and Internationalization COMPETE 2020 and the Lisboa 2020 under the PORTUGAL 2020 Partnership Agreement, and through the Portuguese National Innovation Agency (ANI) as a part of project CHIC POCI-010247-FEDER-024498. And also by national funds through the FCT - Fundação para a Ciência e a Tecnologia, I.P., as part of project UID/CED/00194/2019, SCReLProg.

Daniela Pedrosa wishes to thank Fundação para a Ciência e Tecnologia (FCT) and CIDTFF (UID/CED/00194/2019) - Universidade de Aveiro, Portugal, for Stimulus of Scientific Employment - CEECIND/00986/2017 Individual Support 2017.

\section{References}

1. OMG - Object Management Group: Business Process Model and Notation (BPMN), Version $2.0(2011)$

2. Morais, C., Pedrosa, D., Fontes, M.M., Cravino, J., Morgado, L.: Detailing an e-Learning course on software engineering and architecture using BPMN. In: Queirós, R., Portela, F., Pinto, M., Simões, A. (eds.) First International Computer Programming Education Conference (ICPEC 2020), pp. 17:1-17:8. Schloss Dagstuhl-Leibniz-Zentrum für Informatik, Dagstuhl, Germany (2020)

3. Caeiro-Rodriguez, M.: Making teaching and learning visible: how can learning designs be represented? In: Proceedings of the Seventh International Conference on Technological Ecosystems for Enhancing Multiculturality, pp. 265-274. ACM, León Spain (2019)

4. Savić, G., Segedinac, M., Milenković, D., Hrin, T., Segedinac, M.: A model-driven approach to e-course management. Aust. J. Educ. Technol. (2017). https://doi.org/10.14742/ajet.3124

5. van Es, R., Koper, R.: Testing the pedagogical expressiveness of IMS LD. Educ. Technol. Soc. 9, 229-249 (2006)

6. Zimmerman, B.J.: From cognitive modeling to self-regulation: a social cognitive career path. Educ. Psychol. 48, 135-147 (2013). https://doi.org/10.1080/00461520.2013.794676

7. Panadero, E.: A review of self-regulated learning: six models and four directions for research. Front. Psychol. 8, 422 (2017). https://doi.org/10.3389/fpsyg.2017.00422

8. Panadero, E., Järvelä, S.: Socially shared regulation of learning: a review. Eur. Psychol. 20, 190-203 (2015). https://doi.org/10.1027/1016-9040/a000226

9. Harley, J.M., Taub, M., Bouchet, F., Azevedo, R.: A framework to understand the nature of co-regulated learning in human-pedagogical agent interactions. In: SRL@ET (2012)

10. Bowers, J., Kumar, P.: Students' perceptions of teaching and social presence: a comparative analysis of face-to-face and online learning environments. Int. J. Web-Based Learn. Teach. Technol. 10, 27-44 (2015). https://doi.org/10.4018/ijwltt.2015010103

11. Dabbagh, N., Kitsantas, A.: Personal learning environments, social media, and self-regulated learning: a natural formula for connecting formal and informal learning. Internet High. Educ. 15, 3-8 (2012). https://doi.org/10.1016/j.iheduc.2011.06.002

12. Broadbent, J.: Comparing online and blended learner's self-regulated learning strategies and academic performance. Internet High. Educ. 33, 24-32 (2017). https://doi.org/10.1016/j.ihe duc.2017.01.004

13. Broadbent, J., Poon, W.L.: Self-regulated learning strategies \& academic achievement in online higher education learning environments: a systematic review. Internet High. Educ. 27, 1-3 (2015). https://doi.org/10.1016/j.iheduc.2015.04.007 
14. Pedrosa, D., et al.: Challenges implementing the simprogramming approach in online software engineering education for promoting self and co-regulation of learning. In: 2020 6th International Conference of the Immersive Learning Research Network (iLRN), pp. 236-242. IEEE, San Luis Obispo (2020)

15. Kebritchi, M., Lipschuetz, A., Santiague, L.: Issues and challenges for teaching successful online courses in higher education: a literature review. J. Educ. Technol. Syst. 46, 4-29 (2017). https://doi.org/10.1177/0047239516661713

16. Sharp, L.A., Sharp, J.H.: Enhancing student success in online learning experiences through the use of self-regulation strategies. J. Excell. Coll. Teach. 27, 57-75 (2016)

17. Pérez-Álvarez, R., Maldonado-Mahauad, J., Pérez-Sanagustín, M.: Tools to support selfregulated learning in online environments: literature review. In: Pammer-Schindler, V., PérezSanagustín, M., Drachsler, H., Elferink, R., Scheffel, M. (eds.) EC-TEL 2018. LNCS, vol. 11082, pp. 16-30. Springer, Cham (2018). https://doi.org/10.1007/978-3-319-98572-5_2

18. Viberg, O., Khalil, M., Baars, M.: Self-regulated learning and learning analytics in online learning environments: a review of empirical research. In: Proceedings of the Tenth International Conference on Learning Analytics \&amp; Knowledge. pp. 524-533. Association for Computing Machinery, New York (2020)

19. Winne, P.: Learning analytics for self-regulated learning. In: Lang, C., Siemens, G., Wise, A.F., Gaševic, D. (eds.) The Handbook of Learning Analytics. pp. 241-249. Society for Learning Analytics Research (SoLAR), Alberta (2017)

20. Kim, D., Yoon, M., Jo, I.-H., Branch, R.M.: Learning analytics to support self-regulated learning in asynchronous online courses: a case study at a women's university in South Korea. Comput. Educ. 127, 233-251 (2018). https://doi.org/10.1016/j.compedu.2018.08.023

21. Hassani, A., Ghanouchi, S.A.: Modeling of a collaborative learning process in the context of MOOCs. In: 2016 Third International Conference on Systems of Collaboration (SysCo), pp. 1-6. IEEE, Casablanca (2016)

22. Hammad, R., Odeh, M., Khan, Z.: Towards a generalised e-learning business process model. In: BUSTECH 2017 : The Seventh International Conference on Business Intelligence and Technology, pp. 20-28. IARIA, Athens (2017)

23. Subramanian, V.: Towards business process management based workplace e-learning. In: 2016 IEEE 16th International Conference on Advanced Learning Technologies (ICALT), pp. 555-557. IEEE, Austin (2016)

24. Pereira, A., Mendes, A.Q., Morgado, L., Amante, L., Bidarra, J.: Universidade Aberta's pedagogical model for distance education: a university for the future. Universidade Aberta, Lisbon, Portugal (2008)

25. Guia Informativo - Ensino Aprendizagem - Orientações Metodológicas. https://www2.uab. pt/guiainformativo/detailmenu.php?content $=24$

26. Web Service API Functions. https://docs.moodle.org/dev/Web_service_API_functions

27. Prieto, L.P., Asensio-Pérez, J.I., Muñoz-Cristóbal, J.A., Jorrín-Abellán, I.M., Dimitriadis, Y., Gómez-Sánchez, E.: Supporting orchestration of CSCL scenarios in web-based distributed learning environments. Comput. Educ. 73, 9-25 (2014). https://doi.org/10.1016/j.compedu. 2013.12.008

28. Grann, J., Bushway, D.: Competency map: visualizing student learning to promote student success. In: Proceedings of the Fourth International Conference on Learning Analytics and Knowledge, pp. 168-172. Association for Computing Machinery, New York (2014)

29. Kim, J., Jo, I.-H., Park, Y.: Effects of learning analytics dashboard: analyzing the relations among dashboard utilization, satisfaction, and learning achievement. Asia Pac. Educ. Rev. 17(1), 13-24 (2015). https://doi.org/10.1007/s12564-015-9403-8 
30. Gašević, D., Dawson, S., Rogers, T., Gasevic, D.: Learning analytics should not promote one size fits all: The effects of instructional conditions in predicting academic success. Internet High. Educ. 28, 68-84 (2016). https://doi.org/10.1016/j.iheduc.2015.10.002

31. Sedrakyan, G., Malmberg, J., Verbert, K., Järvelä, S., Kirschner, P.A.: Linking learning behavior analytics and learning science concepts: designing a learning analytics dashboard for feedback to support learning regulation. Comput. Hum. Behav. 107, 105512 (2020). https://doi. org/10.1016/j.chb.2018.05.004 